(a) Egg Number

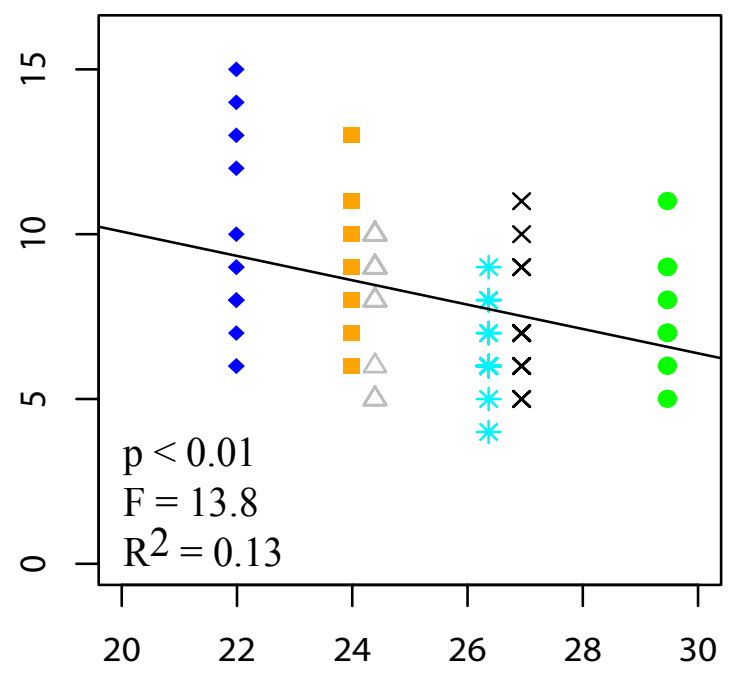

(d) Total Testis (vol)

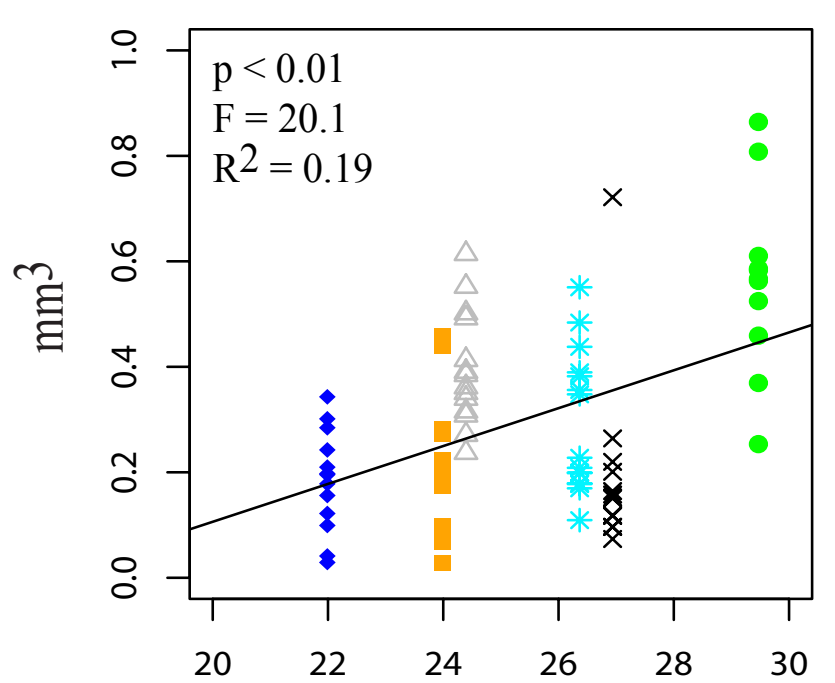

(b) $\quad$ Egg Size (vol)

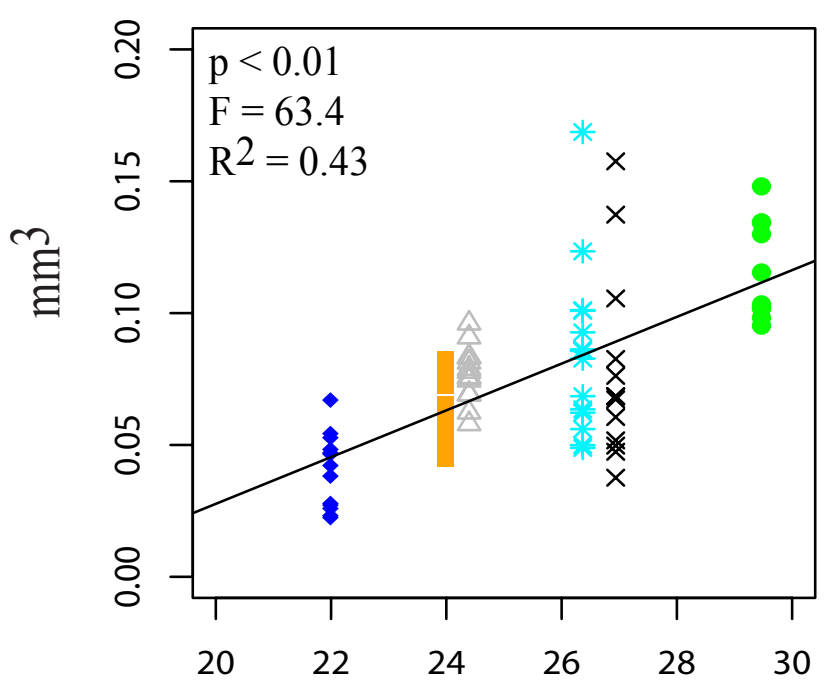

(e) Total Gonad (vol)

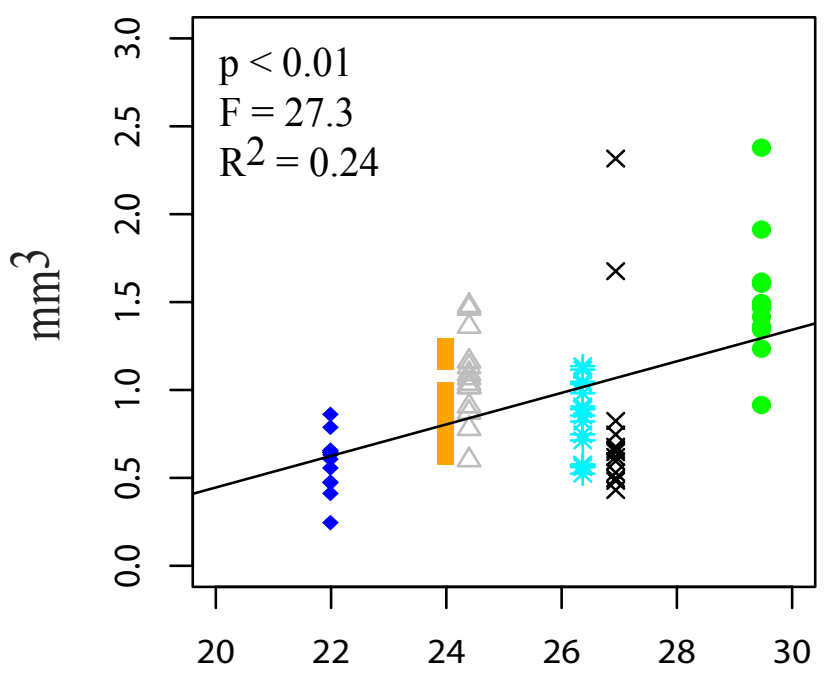

(c) Total Egg (vol)

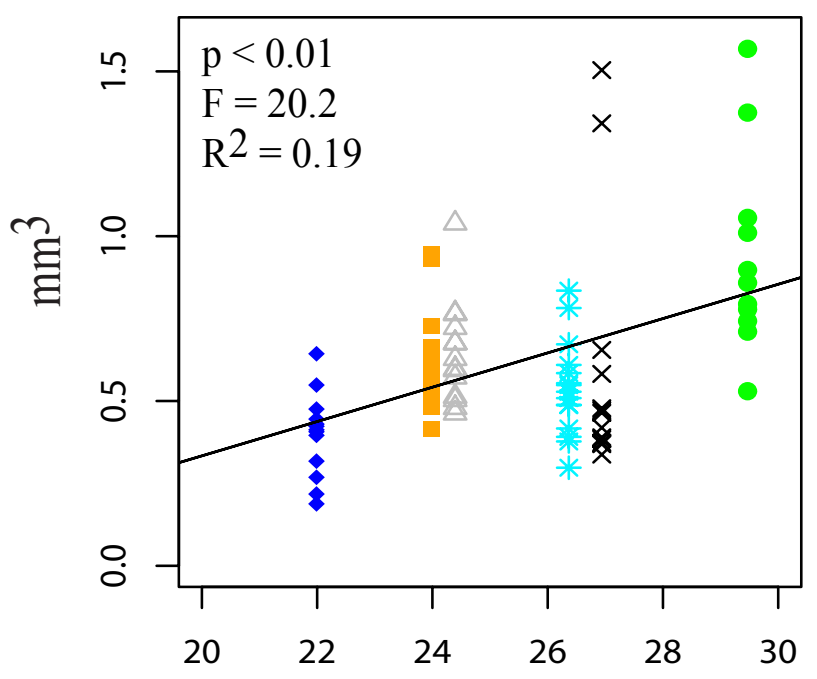

\section{Sampled locations}

- Kochi

Miyazaki

$\triangle$ Penghu

$\times$ Lyudao

* Wanlitung

- Indonesia 